\title{
水銀法ボウ硝電解生成過硫酸の蒸留ならびに過酸化水素精留 に関する基碐的研究*
}

\author{
Studies on Distillation of Persulfate Solution by Amalgam Process \\ Electrolysis of Sodium Sulfate Solution and on Rectification of $\mathrm{Hy}$ - \\ drogen Peroxide Solution
}

\author{
山下正通**, 窪 川 真 男** \\ Masamichi Yamashita, Masao Kubokawa, \\ 日 根 文 男***, 吉 沢 四 郎*** \\ Fumio Hine Shiro Yoshizawa
}

\section{1 緒言}

水銀法ボウ硝電解による生成過硫酸”より過酸化水素 を製造する目的で，その蒸留ならびに蒸留過酸化水素の 精留を化学工学的に検討し, それらの基磪的研究を行な った。

本報では，溶存水銀の影響2)のほとんど認められない 電解生成過硫酸の蒸留および, 溶存水銀の含まない希薄 過酸化水素の精留を行ない，さらに，これらを化学工学 的に解析するに必要なカン（午）液の蒸留特性を求め た.

なお，水銀法ボウ硝電解による生成過硫酸より過酸化 水素を製造する際の原単位を求め, 工業化への基磷的資 料を付記した。

\section{2 過酸化水素の製造}

\section{1 過硫醎の分解反応機楎}

過硫酸の分解機構に関する研究は古くからなされてい る.

たとえば，Elbs ${ }^{3)}$ は過硫酸を加水分解すると希硫酸 中では酸素，濃硫酸中では過酸化水素をそれぞれ遊離す ることを認めた．また $\mathrm{Caro}^{4}$ は強酸性の過硫酸溶液中 にカロ一酸の生成されていることを発見し，さらに，

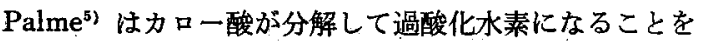
見いだしている。

比較的安定な過硫酸塩の分解反応機構に対しては最近 に至るまで多くの人々によって研究がなされてきてい る.

たとえば, Kailan' ${ }^{6)} \mathrm{pH}$ に依存してその反応形式

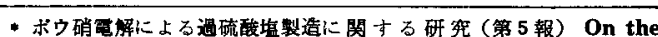
Production of Persulfate by Electrolysia of Sodium Sulfate Solution (Part 5)

昭和 40 年 10 月 9 日化学関保学協会秋季講演会 (東京) にて講演

** 同志社大学工学部 (京都市上京区今出川通鳥丸)

*** 京都大学工学部（京都直在京区吉田本町）
が異なることを指摘しており，Kolthoff7 らは，さらに それらの反応形式を詳細に解明している。

すなわち，Kolthoff は同位元素 ${ }^{18} \mathrm{O}$ を含む水溶液中 で過硫酸カリの熱分解を行ない，その反応形式を 2 つに 大別している、1つは無触媒反応で，中性またはアルカ リ性溶液中で起こり，水が酸素の供給源となっており， 他の 1 つ酸触媒反応で, 酸性溶液中で起こり, 過硫酸 イオンそのものが酸素の供給源となっていることを指摘 した.

過硫酸の無触媒反忘は (1) 式のごとく示される.

$$
\mathrm{S}_{2} \mathrm{O}_{8}{ }^{2-} \stackrel{k_{1}}{\longrightarrow} 2 \mathrm{SO}_{4}^{-}
$$

酸触媒反応は, 無触媒反応とは無関係に独立して起こ り，次のごとき反応を示す.

$$
\begin{aligned}
& \mathrm{S}_{2} \mathrm{O}_{8}{ }^{2-}+\mathrm{H}^{+} \stackrel{k_{2}}{\longrightarrow} \mathrm{HS}_{2} \mathrm{O}_{8}^{-} \\
& \mathrm{HS}_{2} \mathrm{O}_{8}{ }^{-} \longrightarrow \mathrm{SO}_{4}+\mathrm{HSO}_{4}^{-}
\end{aligned}
$$

この際, 酸性の強弱により, その反応形式が 2 つに分 けられる.

i）弱酸性溶液中では $\mathrm{SO}_{4}$ は速かに分解して

$$
\mathrm{SO}_{4} \rightarrow \mathrm{SO}_{3}+\frac{1}{2} \mathrm{O}_{2}
$$

となる゙

ii）強酸性溶液中では $\mathrm{SO}_{4}$ は加水分解をうけてカ口 一酸を生じる゙.すなわち,

$$
\mathrm{SO}_{4}+\mathrm{H}_{2} \mathrm{O} \longrightarrow \mathrm{H}_{2} \mathrm{SO}_{5}
$$

となる。

さらに, カ口一酸の加水分解に関する研究は Bunton, Brodskii ${ }^{10)}$ らによって, 同位元素 ${ }^{18} \mathrm{O}$ を用いてなされ， -O-O- 結合は切断されることなく反応することが確め られた.

$$
\mathrm{S}_{2} \mathrm{O}_{8}{ }^{2-} \rightarrow \mathrm{SO}_{5}{ }^{2-} \rightarrow \mathrm{H}_{2} \mathrm{O}_{2} \rightarrow \mathrm{O}_{2}
$$

すなわち, 力口一酸は加水分解をらけ, 過酸化水素を 生成し, 直ちに次のごとき反応により酸素を発生するも のと考えられる

$$
\mathrm{S}_{2} \mathrm{O}_{8}{ }^{2-}+\mathrm{H}_{2} \mathrm{O}_{2} \longrightarrow 2 \mathrm{HSO}_{4}^{-}+\mathrm{O}_{2}
$$




$$
\mathrm{SO}_{5}{ }^{2-}+\mathrm{H}_{2} \mathrm{O}_{2} \longrightarrow \mathrm{SO}_{4}{ }^{2-}+\mathrm{H}_{2} \mathrm{O}+\mathrm{O}_{2}
$$

以上，無触媒反応㧍よび酸触媒反応を通じて，すなわ ち，すべての $\mathrm{pH}$ 領域において，次のごとき 1 次反応 が過硫酸塩の分解反応飞対して与えられている ${ }^{7), 22) . ~}$

$$
\begin{aligned}
& -d\left[\mathrm{~S}_{2} \mathrm{O}_{8}{ }^{2-}\right] / d t=k_{o b s}\left[\mathrm{~S}_{2} \mathrm{O}_{8}{ }^{2-}\right] \\
& k_{o b s}=k_{1}+k_{2}\left[\mathrm{H}^{+}\right]
\end{aligned}
$$

この式は，無触媒反応と酸触媒反応とは亘に独立して 起こり，反応の律速段階はそれぞれ（1），(2) 式にある ことを意味している。

\section{2 電解生成過硫酸の蒸留}

水銀法ボウ硝電解生成過硫酸を加水分解することによ

ク，過酸化水素を製造するのが目的である.

この電解生成過硫酸は強酸性溶液であり, しかも,ご く微量の溶存水銀が含まれている2゙.

この過硫酸蒸留の際, 過酸化水素の収率を增すために は生成した過酸化水素を速かにカン液室外に捕集する必 要がある.

この理由は, 主として反応 (7),(8) 式に基づく過酸 化水素停漁による自己分解を防止するためである.

そこで，過硫酸蒸留に際しては低温減圧蒸留法を採用 し，乙加も，原液（過硫酸）と生成過酸化水素の再接触 による自己分解を防ぐために，原理的には単蒸留方式を 用い，速かに加水分解を行ならことにした．

この際, 生成過酸化水素の濃度は希薄であり, したが って，精留操作をつぎ施す必要がある.

この精留の際には，蒸留時に過硫酸溶液からひまっ同 伴された溶存水銀の除去を行ならことはいらまでもな $\checkmark$.

2.2 .1 蒸留方法 電解生成過硫酸を加水分解して 過酸化水素を製造するのに，図 1 亿示すよ 塔を用いた。

蒸留方法としては，過硫酸ソーダを加水分解して得

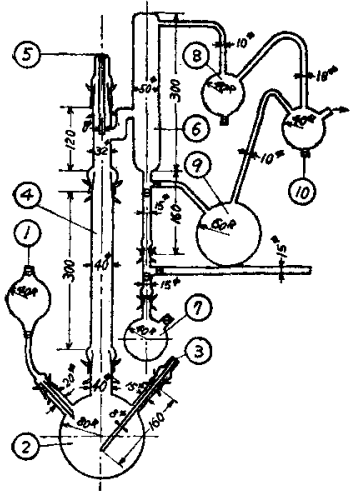
られる4成分 $\left(\mathrm{H}_{2} \mathrm{SO}_{4}-\right.$ $\left.\mathrm{Na}_{2} \mathrm{SO}_{4}-\mathrm{H}_{2} \mathrm{O}_{2}-\mathrm{H}_{2} \mathrm{O}\right)$ 系 のフラッシュ蒸留 ${ }^{21}$ を行 なう必要がある。

しかし，本蒸留の場 合, $\mathrm{H}_{2} \mathrm{SO}_{4}-\mathrm{Na}_{2} \mathrm{SO}_{4}$ 系と $\mathrm{H}_{2} \mathrm{O}_{2}-\mathrm{H}_{2} \mathrm{O}$ 系のそれぞれ の蒸気圧問の差の著しい ことを認めたので $\mathrm{H}_{2} \mathrm{O}_{2}$ $-\mathrm{H}_{2} \mathrm{O}$ 系のみに着目して 回分式単蒸留 ${ }^{13}$ を行な5 ことにした.すなわち， $\mathrm{H}_{2} \mathrm{SO}_{4}, \mathrm{Na}_{2} \mathrm{SO}_{4}, \mathrm{H}_{2} \mathrm{O}_{2}$ $1:$ 原液注入口, $2:$ カン液至
$3,5:$ 温度計, $4:$ 蒸留塔 $6:$ 全縮器, $7:$ 留出液受器

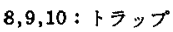

図 1 隇圧回分式堂蒸留塔

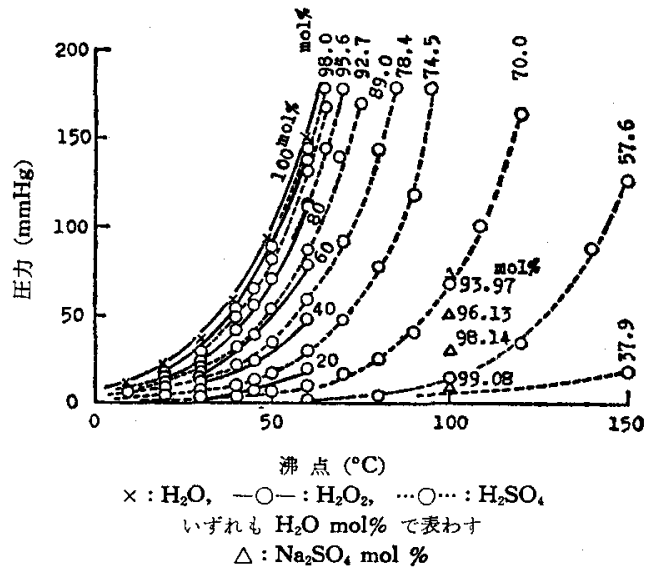

図 $2 \mathrm{Na}_{2} \mathrm{SO}_{4}, \mathrm{H}_{2} \mathrm{SO}_{4}, \mathrm{H}_{2} \mathrm{O}_{2}, \mathrm{H}_{2} \mathrm{O}$ の蒸気圧曲線

に際して前二者と後二者を分留することは，それはど困 難ではなさそうであると考えられる (図 2 参照).

そこで，適当な蒸留条件を選ぶならば，電解生成過硫 酸より過酸化水素の蒸留が行なえるはずである.

2.2.2 蒸留結果 過硫酸溶液を加水分解して得ら れた過酸化水素の収量と蒸留温度および圧力の関係を求 め，最適の蒸留条件を検討することにした。

まず電解生成過硫酸溶液をそのまま単蒸留した場合に ついて, 過酸化水素の渡度と蒸留温度ならびに圧力の測 定結果を求め表 1 亿示した。ただし，初期過硫酸溶液漶 度 $0.145 \mathrm{~mol} / l$ のものを用いた。この結果より, 単蒸留 の条件として，速かに過酸化水素の沸点に到達しらるよ らに蒸留カン内の気压を調整してやる必要があり,むし

\begin{tabular}{|c|c|c|c|c|c|c|c|c|}
\hline \multirow{3}{*}{ 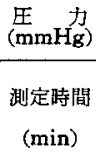 } & \multicolumn{4}{|c|}{20} & \multicolumn{4}{|c|}{40} \\
\hline & \multicolumn{2}{|c|}{ 温度 $\left({ }^{\circ} \mathrm{C}\right)$} & \multicolumn{2}{|c|}{ 留山液 } & \multicolumn{2}{|c|}{ 温暲 $\left({ }^{\circ} \mathrm{C}\right)$} & \multicolumn{2}{|c|}{ 留出 波 } \\
\hline & 液側 & 気体側 & $\begin{array}{l}\text { 䕃 } \\
(\mathrm{wt} \%)\end{array}$ & $\begin{array}{l}\text { 容栱 } \\
(\mathrm{m} l)\end{array}$ & 㳸㑡 & 兴体側 & $\begin{array}{l}\text { 濃 } \\
(w t \%)\end{array}$ & $\begin{array}{l}\text { 容 栍 } \\
(\mathrm{m} l)\end{array}$ \\
\hline 10 & 23 & 43 & & & 34 & 50 & & \\
\hline 15 & & & 0.0359 & 154 & 38 & 50 & 0.0476 & 214 \\
\hline 20 & & & & & 40 & 50 & & \\
\hline 25 & 29 & 37 & & & 40 & 52 & & \\
\hline 30 & 30.5 & 40 & & & & & & \\
\hline 35 & 32 & 41 & 0.0222 & 184 & 40 & 56 & & \\
\hline 45 & 35 & 47 & & & 46 & 58 & & \\
\hline 50 & & & 0.0139 & 158 & & & 0.0750 & 350 \\
\hline 55 & 40 & 49.5 & & & & & & \\
\hline 60 & & & & & 72 & 66 & & \\
\hline 65 & 46 & 51 & 0.0344 & 134 & & & & \\
\hline 70 & & & & & & & 1.2820 & 141 \\
\hline 75 & 52 & 60 & & & & & & \\
\hline 80 & & & 0.8520 & 70 & & & & \\
\hline 収量 (g) & & & 1.26 & & & & 1.814 & \\
\hline 収承 $(\%)$ & & & 12.05 & & & & 36.3 & \\
\hline
\end{tabular}
ろ,あまり減圧するより $40 \mathrm{mmHg}$ 程度の真空度の方

表 1 過硫酸溶液単蒸留測定結果 
が $20 \mathrm{mmHg}$ の場合よりも過酸化水素 収率のよいこ とが認められた。これは図2から明らかなよらに，硫酸 および 過酸化水素溶液中の水の $\mathrm{mol} \%$ と沸点と圧力の 関倸を比べてみると，同一気圧における硫酸溶液の沸点 が著しく高く，乙かも，水の同一 $\mathrm{mol} \%$ の硫酸および 過酸化水素の蒸気圧曲線の沸点の差は圧力が増すほど大 きくなっている.

それゆえ, 電解生成過硫酸溶液を酸触媒反応により過 酸化水素をうるには，過酸化水素自体が分解されない温 度範囲内 $\left(90^{\circ} \mathrm{C}\right.$ 以下) で，できるだけ高温側すなわち 高圧側で蒸留した方が，硫酸溶液のひまつ同伴を少なく して容易に過酸化水素をカン液室から分離留出しらるこ とになる.したがって，その蒸留行程をできるだけ速か にして，かつ，硫酸溶液のひまつ同伴などによる 2 次的 な過酸化水素の分解を抑制することにより，過硫酸溶液 からの過酸化水素の収率を増大させることができる.

\section{表 2 過硫酸溶液加水分解}

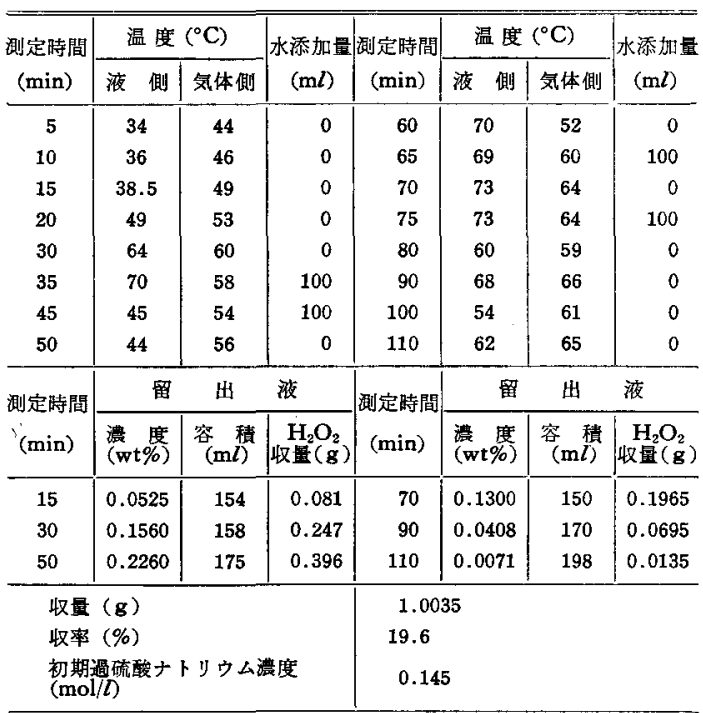

ついで，蒸留中に水を添加して，いわゆる加水分解を 試みた。 その結果を表 2 亿示す．この結果，水添加によ る好影響はそれほど認められなかった。これは，カン室 液中の過硫酸濃度が希薄なため，またすでに多くの水分 を含んでいたため，水添加の効果が現われなかったもの と考えられる。

\section{3 過酸化水秦精留に関する基檚的研究}

\section{1 過酸化水素の分解反応機構}

液相触媒作用に上る過酸化水素分解反応機構记ついて は, 古くから多くの研究がなされ幾多の詳細な総説があ

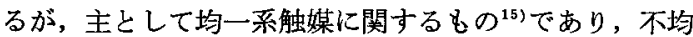
一系触媒に関するものはわずかしかない(16)。

その他, Schumb ${ }^{17)}$ 注濃厚過酸化水素の安定性につ、
表 3 各種温度における $90 \% \mathrm{H}_{2} \mathrm{O}_{2}$ の安定 性 ${ }^{17}$ )

\begin{tabular}{c|c}
\hline \hline 温 度 $\left({ }^{\circ} \mathrm{C}\right)$ & 分解率 $(\%)$ \\
\hline 30 & $1 /$ 年 \\
66 & $1 /$ 週 \\
100 & $2 /$ 日 \\
140 & $100 / 0$ \\
\hline
\end{tabular}

て調べ，純粋であれば非常に 安定であることを示してい る.たとえば, 表 3 のごとく， $90 \% \mathrm{H}_{2} \mathrm{O}_{2}$ の分解率は温度を $140^{\circ} \mathrm{C}$ にまで上げなければほ とんど変化なく非常に小さい ことがわかる.しかし，水で 希釈したものに対しては，15〜85\% の間では温度笧囲 $50 \sim 100^{\circ} \mathrm{C}$ にて, $10^{\circ} \mathrm{C}$ 上昇するごとに 分解速度は 2.2 倍になる.ついで，pH および各種金属イオンの過酸化 水素分解率に及ほす影響についても言及している。 ず， $\mathrm{pH}$ の影響については， $\mathrm{pH}=4$ なるときが 分解率 が最も小さく安定性がよく，これを支配する因子は $\left[\mathrm{H}^{+}\right]$であるとしている(図 3 参照)

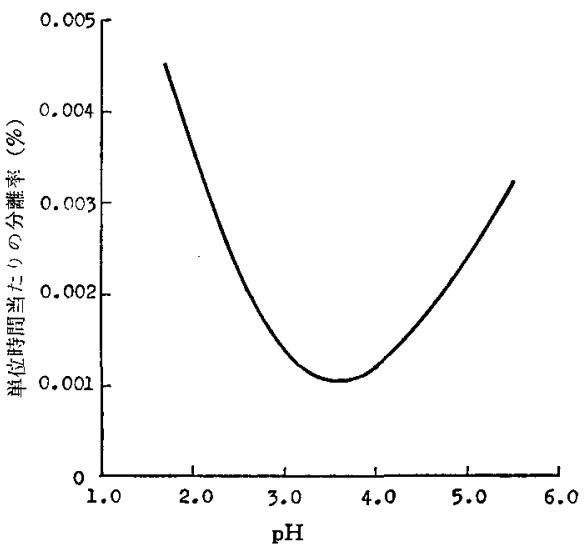

図 3 過酸化水素分解染に及ぼす $\mathrm{pH}$ の影響17)

\section{2 カン液の蒸留特性について}

電解生成過硫酸溶液を回分式減圧単蒸留して得られた 希薄過酸化水素溶液を精留して濃縮するに際し，溶存水 銀の除去, 過酸化水素の安定性についてはすでに検討を 行なってきた。

そこで，本節では，基礎的に過酸化水素溶液の精留に 関して検討を行ない精留条件を求めることにした．

まず，カン液としての過酸化水素溶液について Dühring 線図を求め蒸気压と沸点の関係をは汢あし，つい で，一定蒸気圧に扔ける気液平衡曲線を全濃度領域につ いて検討した。

これら資料を求める際にカン液中の安定性をよくする ために $\mathrm{pH} 4$ に調整（図 3 参照）した。

測定装置として, Othmer 型気液平衡測定装置 ${ }^{18)}$ を改 良して減圧下で測定しらるものを用いた。

3.2.1 $\mathrm{H}_{2} \mathrm{O}_{2}-\mathrm{H}_{2} \mathrm{O} 2$ 成分系 Dühring 線図試料 の過酸化水素溶液の $\mathrm{pH}$ を調整して,分解率の最も小さ い $\mathrm{pH} 4$ のもとで Dühring 線図を求めることにした.

この Dühring 線図を求めることは，あらゆる点にお ける蒸気圧あるい沙沸点をこの線図より推測しらる利点 
があり，平衡蒸留を行なら際に欠

くことのできない基嘫資料ともな

り，非常に有用な手段となる. $\mathrm{H}_{2} \mathrm{O}_{2}-\mathrm{H}_{2} \mathrm{O}$ Dühring 線図は，亦 る濃度において示す同じ蒸気圧の 過酸化水素溶液の 沸点 $Y$ と基準 液体である水の沸点 $X$ を測定し， それぞれ，縱，横軸の座標にプロ ットして直線関係を得た図を示 し，使用便利のため横軸はさらに 水の飽和温度に対応する蒸気圧も 参考に目盛ってある (図 4 参照).

Othmer 改良型気液平衡測定装 置で測定した各種濃度過酸化水素 溶液の $X, Y$ の值を表 4 に示し た.

つぎに,これら $X, Y$ の測定值 を最小二乗法により回帰直線を算 出した (表 5 参照)。

また，求めた Dühring 線図の 再現性を確める意味で, この Dúhring 線図のYの各点における過 酸化水素濃度と水蒸気圧との関係 を求罒 5 に示した。この図によ り, 各沸点における $\mathrm{Y}$ の值の再現 性のよいことがわかる。

さらに，回帰直線を求める際，

Gauss 最小二乗法で求めた $\alpha, \beta$ の推定値 $a, b$ に対する検定を行

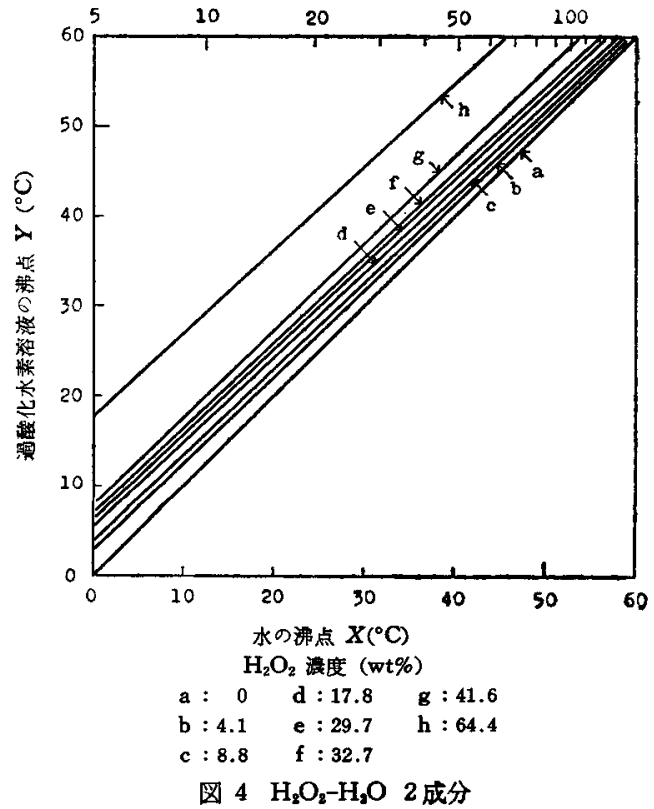

表 4 各種濃度における $X, Y$ の実測值

\begin{tabular}{|c|c|c|c|c|c|c|c|c|c|c|c|c|c|c|}
\hline \multirow{3}{*}{$\begin{array}{c}\text { 测定度数 } \\
n\end{array}$} & \multicolumn{8}{|c|}{$\mathrm{H}_{2} \mathrm{O}_{2}$ 渃度 $(\mathrm{wt} \%)$} & \multicolumn{6}{|c|}{$\mathrm{H}_{2} \mathrm{O}_{2}$ 濃度 $(\mathrm{wt} \%)$} \\
\hline & \multicolumn{2}{|c|}{4.08} & \multicolumn{2}{|c|}{8.8} & \multicolumn{2}{|c|}{17.8} & \multicolumn{2}{|c|}{29.7} & \multicolumn{2}{|c|}{32.7} & \multicolumn{2}{|c|}{41.6} & \multicolumn{2}{|c|}{64.4} \\
\hline & $X$ & $Y$ & $X$ & $Y$ & $X$ & $Y$ & $X$ & $Y$ & $\boldsymbol{X}$ & $Y$ & $X$ & $Y$ & $X$ & $Y$ \\
\hline 1 & 28.8 & 30.3 & 19.5 & 22.8 & 17.5 & 22.2 & 9.7 & 14.2 & 23.3 & 29.3 & 25.2 & 32.8 & 9.7 & 27.0 \\
\hline 2 & 33.1 & 35.1 & 25.9 & 28.9 & 27.2 & 31.9 & 15.3 & 22.0 & 28.7 & 35.0 & 28.7 & 36.1 & 11.3 & 28.5 \\
\hline 3 & 36.8 & 38.9 & 30.7 & 33.8 & 32.7 & 36.1 & 24.4 & 30.5 & 32.2 & 38.1 & 32.2 & 39.9 & 18.5 & 36.5 \\
\hline 4 & 40.6 & 42.1 & 34.0 & 36.7 & 36.8 & 40.3 & 28.7 & 34.0 & 36.8 & 42.4 & 35.8 & 44.0 & 27.8 & 44.7 \\
\hline 5 & 43.5 & 45.0 & 37.9 & 40.2 & 39.9 & 43.4 & 32.9 & 38.1 & 40.9 & 46.4 & 40.2 & 47.0 & 30.6 & 47.9 \\
\hline 6 & 47.1 & 48.5 & 40.6 & 42.9 & 43.2 & 46.8 & 36.7 & 41.8 & 43.2 & 48.8 & 42.9 & 50.1 & 33.1 & 50.4 \\
\hline 7 & 50.7 & 52.0 & 43.8 & 46.2 & 46.3 & 49.4 & 44.0 & 48.9 & 46.4 & 51.9 & 44.4 & 51.9 & 35.1 & 52.1 \\
\hline 8 & 54.1 & 55.0 & 46.7 & 49.0 & 48.5 & 51.8 & 45.8 & 50.6 & 49.6 & 55.0 & 45.1 & 53.0 & 38.5 & 54.5 \\
\hline 9 & 59.2 & 60.0 & 48.5 & 50.6 & 51.2 & 54.0 & 48.0 & 52.3 & 53.2 & 58.0 & - & $\ldots$ & 40.2 & 56.1 \\
\hline 10 & - & - & 50.2 & 52.2 & 52.2 & 54.9 & 49.6 & 54.0 & - & - & - & - & 43.2 & 59.2 \\
\hline 11 & - & - & 53.6 & 55.0 & 54.4 & 57.1 & 52.2 & 56.7 & - & - & - & - & - & - \\
\hline 12 & - & - & - & - & - & - & 53.9 & 58.1 & - & - & - & - & - & - \\
\hline
\end{tabular}

表 5 各種浱度における回帰直線 $Y=a+b X$ の算出値

\begin{tabular}{|c|c|c|c|c|c|c|c|}
\hline & \multicolumn{4}{|c|}{$\mathrm{H}_{2} \mathrm{O}_{2}$ 湿度 $(\mathrm{wt} \%)$} & \multicolumn{3}{|c|}{$\mathrm{H}_{2} \mathrm{O}_{2}$ 濃度 $(\mathrm{wt} \%)$} \\
\hline & 4.08 & 8.84 & 17.8 & 29.7 & 32.7 & 41.6 & 64.4 \\
\hline$\Sigma X_{i}$ & 393.9 & 431.4 & 449.9 & 441.3 & 354.3 & 294.5 & 238.0 \\
\hline $\bar{X}$ & 43.77 & 39.22 & 40.9 & 36.78 & 39.37 & 36.81 & 28.8 \\
\hline$\Sigma Y_{i}$ & 406.9 & 458.3 & 487.9 & 501.2 & 404.9 & 354.8 & 456.9 \\
\hline$\overline{\boldsymbol{Y}}$ & 45.21 & 41.66 & 44.35 & 41.77 & 44.99 & 44.35 & 45.69 \\
\hline$\Sigma X_{i}^{2}$ & 18040.25 & 18078.90 & 19729.45 & 23164.10 & 14740.01 & 11239.03 & 9565.38 \\
\hline$\Sigma X_{i} Y_{i}$ & 18580.98 & 19078.29 & 21209.45 & 20734.15 & 16702.01 & 13455.96 & 14375.46 \\
\hline$\Sigma Y_{i}{ }^{2}$ & 19141.97 & 20146.47 & 22825.57 & 18609.27 & 18949.87 & 16128.68 & 22042.67 \\
\hline$S_{X X}$ & 800.56 & 1160.18 & 1328.54 & 2379.53 & 792.46 & 397.85 & 1270.98 \\
\hline$S_{X Y}$ & 772.32 & 1104,60 & 1254.34 & 2302.52 & 762.45 & 394.89 & 1216.74 \\
\hline$S_{Y Y}$ & 745.57 & 1052.02 & 1184.99 & 2230.65 & 733.89 & 393.30 & 1166.91 \\
\hline$a$ & 2.98 & 4.32 & 5.74 & 6.19 & 7.09 & 7.81 & 18.12 \\
\hline$b$ & 0.965 & 0.952 & 0.944 & 0.967 & 0.962 & 0.993 & 0.957 \\
\hline
\end{tabular}

ただし $, a=\bar{Y}-(b \cdot \bar{X}), b=S_{X Y} / S_{X X}$ $S_{X X}=\Sigma X_{i}^{2}-\left(\Sigma X_{i}\right)^{2} / n, S_{X Y}=\Sigma X_{i} Y_{i}-\left(\Sigma X_{i}\right)\left(\Sigma Y_{i}\right) / n$ $S_{Y Y}=\Sigma Y_{i}^{2}-\left(\Sigma Y_{i}\right)^{2} / n$
なった.すなわち, 定直線

$$
y=\alpha+\beta x
$$

において， $\beta=0$ なるときは $y=\alpha$ となり， $x$ より $y$ を 推定することはできないから，この直線は回帰性をもた なくなる。また $\beta \neq 0$ ならば，自由度 $(1, n-2)$ なる

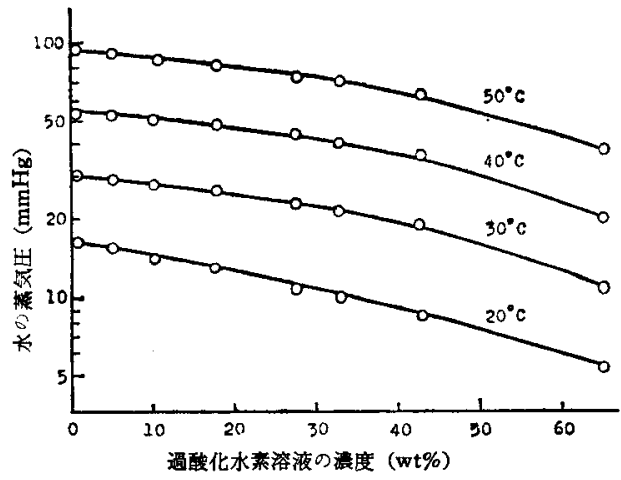

图中の数字は過酸化水菜深液の进点 $\boldsymbol{Y}$ 表わ寸

困 5 Dühring 線図による過酸化水素溶液濃度と 水の蒸気厓との関係 
表 6 直線回垆性の検定結果

\begin{tabular}{c|c|cc}
\hline $\mathrm{H}_{2} \mathrm{O}_{2}$ 瀑度 & $\boldsymbol{F}$ & \multicolumn{2}{|c}{$\boldsymbol{F}_{0.01}(1.6 \sim 1.10)$} \\
\hline $\mathbf{w t} \%)$ & & $(1.7)$ & 12.2 \\
$\mathbf{4 . 0 8}$ & 28680 & $(1.9)$ & 10.6 \\
8.84 & 1384 & $(1.9)$ & 10.6 \\
17.8 & 32.02 & $(1.10)$ & 10.0 \\
29.7 & 16046 & $(1.6)$ & 13.7 \\
32.7 & 1874 & $(1.8)$ & 11.3 \\
41.6 & 4437 & - & - \\
64.4 & - & -
\end{tabular}

差平方和 $S$ の最小値を示す.

$$
S_{E}=S_{y y}-b S_{x y}
$$

本実験の場合の直線回㷌性の検定の結果を表 6 亿示し た.

3.2.2 $\mathrm{H}_{2} \mathrm{O}_{2}-\mathrm{H}_{2} \mathrm{O} 2$ 成分系気液平衡関係 測定条 件として, 圧力を $40 \pm 2 \mathrm{mmHg}$ の範囲に保ち, 気相お よび液相間の温度差をできるだけ小さくなるように保温 し，十分に各相が平衡に達してから組成を分析して気液 平衡曲線を求めた。平衡到達時間は約 6 時間を要した.

表 $7 \mathrm{H}_{2} \mathrm{O}_{2}-\mathrm{H}_{2} \mathrm{O}$ 成分系気液平衡実測值

\begin{tabular}{|c|c|c|c|c|}
\hline 気 & $Y$ & 液 & $x$ & \\
\hline 温度 $\left({ }^{\circ} \mathrm{C}\right)$ & ${ }_{(\mathrm{mol} \%)}^{\text {港 }}$ & 温度 $\left({ }^{\circ} \mathrm{C}\right)$ & 謈 & $\underset{(\mathrm{mmHg})}{\text { 岳 }}$ \\
\hline 47.3 & 93.1 & 49.2 & 50.13 & 39 \\
\hline 44.3 & 96.38 & 45.1 & 63.0 & 38 \\
\hline 40.5 & 98.84 & 39.8 & 74.36 & 36 \\
\hline 38.0 & 99.81 & 39.1 & 85.2 & 40.5 \\
\hline 36.0 & 99.91 & 37.9 & 88.3 & 40.5 \\
\hline 35.5 & 99.99 & 36.6 & 96.6 & 39 \\
\hline
\end{tabular}

その測定結果を表 7 に示した。この際の気相の濃度 (Y) および液相の濃度 $(X)$ はそれぞれ低沸点成分であ るところの水の $\mathrm{mol} \%$ で表わしている.

本操作に扝いて, 過酸化水素の濃度を高濃度にすると 爆発の危険を伴う恐れがあるので，本実験では 50.13 $\mathrm{mol} \%$ 以上 ( $X$ の值では $50.13 \mathrm{~mol} \%$ 以下) の高濃度 に扔ける場合の $X-Y$ 平衡曲線は実測によることをさ け, 熱力学の平衡条件より導き出された Margules 式 ${ }^{19}$ より測定した。

すなわち，低濃度における $X-Y$ 平衡の実測值を Margules 式 (21)，(22) 式に代入し，各組成における活量 係数を求め (15)，(16) 式により，之れぞれ $X ， Y$ を算 出し, 全濃度領域の $X-Y$ 平衡曲 線を求めた（図 6 参 照).

\section{つぎに，その算出法を示す．}

熱力学では，気相と液相とが互に平衡にあるときそ の系の自由エネルギーが極小となることが定義立れてい る，その定義に゙したがって，Gibbs-Duhem の式が導か れている。

$$
X\left(\partial \ln \gamma_{1} / \partial X\right)_{\pi, t}+(1-X)\left(\partial \ln \gamma_{2} / \partial X\right)_{\pi, t}=0 \text { (14) }
$$

ここに, $X$ は液相の低沸点成分のモル分率， $\pi$ 注全圧,

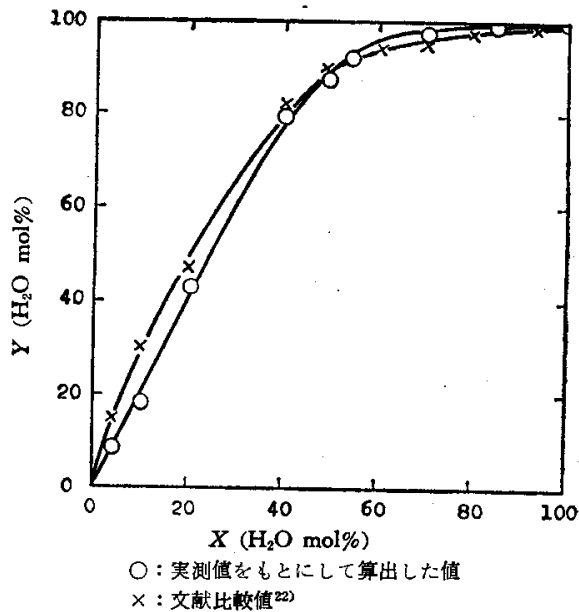

図 $6 X-Y$ 気液平衡曲線 $(\pi=40 \mathrm{mmHg})$

$t$ は温度， $\gamma_{1} ， \gamma_{2}$ はそれぞれ低沸点成分と高沸点成分の 活量係数であり次式により定義されている ${ }^{20)}$.

$$
\begin{aligned}
& r_{1}=\pi y /\left(P_{1} X\right) \\
& r_{2}=\pi(1-y) /\left\{P_{2}(1-X)\right\}
\end{aligned}
$$

ここに，Y は気相の低沸点成分のモル分率， $P_{1}, P_{2}$ は それぞれ低沸点成分と高沸点成分の平衡温度における蒸 気圧である.この $P_{1}, P_{2}$ の平衡温度における関係式と して次式が成立することが知られている ${ }^{21}$.

$$
\begin{aligned}
& \log P_{1}=A-B /(C-t) . \\
& \log P_{2}=-0.05223 A / T+B
\end{aligned}
$$

ここに，(17) 式は水の沸点 $(t)$ と蒸気压 $\left(P_{1}\right)$ の関係 を表わし，

$$
t=0 \sim 60^{\circ} \mathrm{C} \text { では }\left\{\begin{array}{l}
A: \quad 8.10765 \\
B: 1750.286 \\
C: 235.0
\end{array}\right.
$$

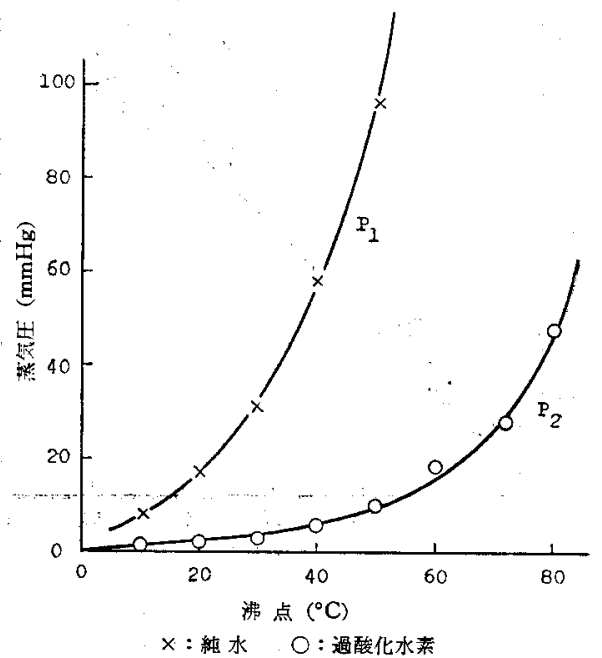

図 7 (17) 式および (18) 式の沸点々蒸気圧 との関係曲線 


$$
t=60 \sim 150^{\circ} \mathrm{C} \text { では }\left\{\begin{array}{l}
A: \quad 7.9668 \\
B: 1668.21 \\
C: 228.0
\end{array}\right.
$$

なる值をとる、また，(18）式は過酸化水素の沸点 $(T)$ 之蒸気圧 $\left(P_{2}\right)$ の関係を表わし

$T=283 \sim 363^{\circ} \mathrm{K}\left(10 \sim 90^{\circ} \mathrm{C}\right)$ の籁围で

$$
\left\{\begin{array}{l}
A: 48530 \\
B: 8.853
\end{array}\right.
$$

なる值をとる，以上 (17)，(18) 式の関係を図示すれば, 図7のごとくなる.

さて，(14）式の解法として，活量係数 $r_{i}$ と組成 $x_{i}$ との関係式より算出する方法を述べることにする。ここ 亿，素子 $i$ は 1 のとき水，2のとき過酸化水素を示す.

いま $r_{i}$ と $x_{i}$ の関数 $Q$ をつぎのごとく定義する.

$$
Q=X_{1} \log r_{1}+X_{2} \log r_{2}
$$

（19）式において，理想溶液の場合には， $X_{1}=r_{1}=1$, $X_{2}=r_{2}=1$ であるから $Q=0$ となり，実在溶液の場合に は次の実験式が成立つ。

$$
Q=X_{1} X_{2}\left[L+M\left(X_{1}-X_{2}\right)+N\left(X_{1}-X_{2}\right)^{2}+\cdots\right]
$$

\begin{tabular}{|c|c|c|c|c|c|}
\hline \multirow{3}{*}{$\begin{array}{c}\text { 㑚定特間 } \\
\text { (min) }\end{array}$} & \multirow{2}{*}{\multicolumn{2}{|c|}{ 蒸留温度 $\left({ }^{\circ} \mathrm{C}\right)$}} & 力 & ע & \multirow{2}{*}{$\frac{\mathrm{H}_{2} \mathrm{O}}{}$} \\
\hline & & & \multicolumn{2}{|c|}{$\mathrm{H}_{2} \mathrm{O}_{2}$} & \\
\hline & 塔 頂 & 塔 店 & $(w t \%)$ & $(\mathrm{mol} \%)$ & $(\mathrm{mol} \%)$ \\
\hline 10 & 28.5 & 25.0 & 0.833 & 0.444 & 99.556 \\
\hline 15 & 30.0 & 25.5 & - & & \\
\hline 25 & 30.5 & 26.5 & - & & \\
\hline 35 & 32.5 & 27.0 & - & & \\
\hline 45 & 32.0 & 27.0 & - & & \\
\hline 55 & 32.0 & 28.0 & - & & \\
\hline 65 & 34.0 & 30.5 & - & & \\
\hline 75 & 36.0 & 32.0 & - & & \\
\hline 85 & 37.0 & 33.5 & - & & \\
\hline 95 & 38.0 & 34.5 & - & & \\
\hline 105 & 38.5 & 35.0 & - & & \\
\hline 115 & 38.5 & 34.5 & 7.16 & 3.93 & 96.07 \\
\hline & & 湍摍率 & 8.6 倍 & & \\
\hline
\end{tabular}

この式で, $L, M, N$ 注数で温度に依存する. Margules 式㧍よび Van Laar $^{33)}$ で満足される系では (20) 式 のらちの第 2 項まで算出すればよい。

表 8 還流比比の場合の回分式精留結果 $(50 \mathrm{mmHg})$ $\mathrm{H}_{2} \mathrm{O}_{2}, \mathrm{H}_{2} \mathrm{O}$ 濃度組成

したがって, Margules 式として (21),(22) 式が導 き出される.

$$
\begin{aligned}
& \log r_{1}=(1-X)^{2}\{L-2(L-M X)\} \\
& \log r_{2}=X^{2}\{M+2(L-M)(1-X)\}
\end{aligned}
$$

\section{算出例}

表 702 段目の $X, Y$ の值を使用して $L, M$ を求め ると次のごとくなる。

$$
\begin{aligned}
r_{1} & =\pi / Y\left(P_{1} X\right) \\
& =(38 \times 0.964) /(72.5 \times 0.63)
\end{aligned}
$$

$$
=0.802
$$

ただし， $P_{1}, P_{2}$ は図 7 より求めた。

$$
\begin{aligned}
r_{2} & =\pi(1-Y) /\left\{P_{2}(1-X)\right\} \\
& =(38 \times 0.036) /(7.54 \times 0.37) \\
& =0.491
\end{aligned}
$$

これら， $r_{1}, r_{2}$ の算出値をそれぞれ (21)，(22) 式に代 入すれ壮

$$
\begin{aligned}
& \log 0.802=0.37^{2}\{L-2(L-M) 0.63\} \\
& \log 0.491=0.63^{2}\{M+2(L-M) 0.37\}
\end{aligned}
$$
となり,

$$
\begin{aligned}
& L=0.799 \\
& M=0.719
\end{aligned}
$$

\section{が求まる。}

つぎに，(27)，(28) 式で求めた定数 $L, M$ を(21)， （22）式に代入し，種々の䈨度における $r_{1} ， r_{2}$ を算出す る.

$$
\begin{aligned}
& \text { さらに, (15),(16) 式より } \\
& \quad \pi=r_{1} P_{1} X+r_{2} P_{2}(1-\mathrm{X})
\end{aligned}
$$

を導き， $\mathrm{X}$ 嶩度に扔ける $r_{1}, r_{2}$ を代入し， $\pi=40 \mathrm{mmHg}$ となるような $P_{1}, P_{2}$ および沸点を図7より決定し， (15)，(16）式にそれぞれの值を代入すると，Xに対する Yの值が求まる.

\section{4 塔式減区精留}

精留を行ならにあたっ て，過酸化水素のような 腐食性液体を取り扱ら場 合に, 精留塔自体の材質 に制限がありしたがっ て，構造も簡単なむのが 要求される。しかも，减 圧下で短時間に精留を行 ない過酸化水素の分解を できるだけ抑制する必要 がある。

本研究の原料のごと く，品質が変動しやす く，処理量が少ない場合 には，回分式精留による 方が操作が容易であるも のと考えられる。

さき回分式精留理論 についてふれたが，実際 に希薄過酸化水素溶液を 精留するに当たって図 8 の装置を濡壁塔として用 いて，ゼロ還流の場合に ついて，塔頂および塔底

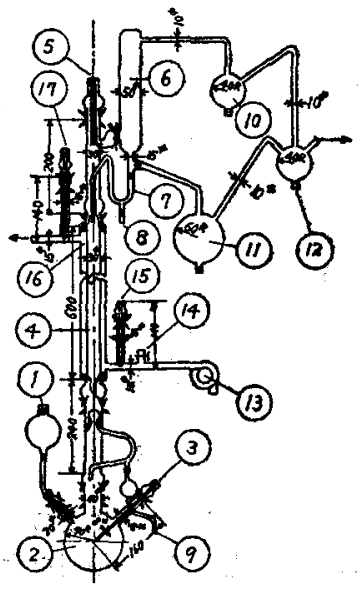

1：原液注入口 2：カン液室 $3,5,15,17:$ 温度計 4:分留茖

6: 分樎器 $7:$ 這流管 8：塔頂留出波採取口 9: 塔底留分探取口

$10,11,12: ト ラ ッ フ ゙$ 13:熱風器 14 : 温度調整 16 ：保温二重管

図 8 塔式減任精留塔 
の濃度を求めた。

精留条件として, 蒸気圧 $50 \mathrm{mmHg}$ に保つように蒸 留温度を調節して行なった。

表 9 は ゼロ 還流すなわち, 回分式単蒸留の場合につい ての測定結果であり，原液の分解を考慮しても約 8.6 倍 に濃縮されていることを示している，ただし，体積は $60 \mathrm{~m} l / 500 \mathrm{ml}$ となる。原液はいずれも $1 \mathrm{wt} \% \mathrm{H}_{2} \mathrm{O}$ 溶液 を用いた。

\section{5 水銀法ボウ硝電解生成過硫酸より 過酸化水素製造の原単位}

中規模水銀法ボウ硝電解により，過硫酸およびカセイ ソーダを製造し, ついで, 電解生成過硫酸を加水分解し て過酸化水素溶液を製造し，さらに，精留した。

この際，ボウ硝 1 トン当たりの水銀法ボウ硝電解（過 硫酸, カセイソーダ，および過酸化水素製造）原単位を 算出し，表 9 に示した。

表 9 水銀法ボウ硝電解 (過硫酸，力セイソーダ， および過酸化水索) 原単位 $\left[\mathrm{Na}_{2}: \mathrm{SO}_{4} 100 \%\right.$ 換算, $1,000 \mathrm{~kg}$ 当たり]

\begin{tabular}{|c|c|c|c|c|c|c|}
\hline 区 & 分 & & 原単 愔 & 実 数* & 備 & 考 \\
\hline 原 & 料 & $\mathrm{Na}_{2} \mathrm{SO}_{4}$ (無 水) & $1,000 \mathrm{~kg}$ & & \multicolumn{2}{|c|}{$\begin{array}{l}\text { 含水 } \\
2,270 \mathrm{~kg}\end{array}$} \\
\hline 電 & 力 & $\begin{array}{l}\text { 電 解 電 力 } \\
\text { 冾凍機動力 } \\
\text { 補助電力 }\end{array}$ & $\begin{array}{c}6,040 \mathrm{kWh} \\
300 \\
40\end{array}$ & & \multicolumn{2}{|c|}{$16 \mathrm{~V}$} \\
\hline \multicolumn{2}{|c|}{ 補助材料 } & 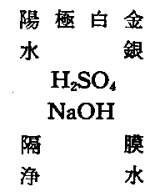 & \begin{tabular}{cc|}
$0.3 \mathrm{~g}$ \\
$0.5 \mathrm{~kg}$ \\
14 & $\mathrm{~kg}$ \\
12 & $\mathrm{~kg}$
\end{tabular} & & & \\
\hline 慗 & 品 & $\begin{array}{c}\mathrm{NaOH} \\
\mathrm{H}_{2} \mathrm{SO}_{4} \\
\mathrm{H}_{2} \mathrm{O}_{2} \\
\mathrm{H}_{2} \\
\mathrm{O}_{2} \text { (㔀生) }\end{array}$ & $\begin{array}{l}563 \mathrm{~kg} \\
692 \mathrm{~kg} \\
183 \mathrm{~kg} \\
158 \mathrm{~m}^{\mathrm{g}}\end{array}$ & $\begin{array}{l}507 \mathrm{~kg} \\
623 \mathrm{~kg} \\
164 \mathrm{~kg} \\
142 \mathrm{~m}^{3} \\
7.9 \mathrm{~m}^{3}\end{array}$ & $\begin{array}{l}\text { 常 } \\
\text { 常 }\end{array}$ & $\begin{array}{l}\text { 王 } \\
\text { 王 }\end{array}$ \\
\hline
\end{tabular}

- 電流效率 $90 \%$ 換算

\section{6 結}

水銀法ボウ硝電解による生成過硫酸の蒸留過酸化水素 の精留を化学工業的検討をする目的で，その基碗的研究 を行なった。

ます，電解生成過硫酸溶液の分解反応機構を調べ，最 適の加水分解条件を求めた。 その結果，実際に水を加え
て加水分解する必要性は認められず, 蒸留操作を速やか にして留出過酸化水素が分縮されることなくカン液室外 に捕集されるよう考慮する必要がある。

蒸留された過酸化水素溶液は希薄であるので，精留す る必要性を認めた. 精留方式として回分式減圧精留塔を 採用し，その精留条件を検討した。

精留の基礎的研究として, 原液 $\left(\mathrm{H}_{2} \mathrm{O}_{2}\right)$ の物性を検 討した.

つぎに，精留カン液としての過酸化水秦溶液の蒸留特 性について調べ, $\mathrm{H}_{2} \mathrm{O}_{2}-\mathrm{H}_{2} \mathrm{O} 2$ 成分系 Dühring 線図, $\mathrm{H}_{2} \mathrm{O}_{2}-\mathrm{H}_{2} \mathrm{O} 2$ 成分系気液平衡曲線を求めた。

おわりに，水銀法ボウ硝電解による生成過硫酸より過 酸化水素製造の原単位を算出し，工業化への基喽的資料 を添えた。

（昭 $40-12-20$ 受理）

$$
\text { 文献 }
$$

1）山下正通. 日根文男，吉沢四郎，本詰 32，366（1964）。

2）山下正通, 澺川真男, 日根交男, 吉沢四郎, 本辡 33, (1965).

3) K. Elbs, O. Schönherr, Z. Elektrochem. 1, 468 (1895).

4) H. Caro, Z. angew. Chem. 11, 845 (1898)

5) H. Palme, ibid. 112, 97 (1920).

6) A. Kailan, L. Olbrich, Wien Akad. Ber. II b. 135, 423(1926).

7) I.M. Kolthoff, I.K. Miller, J.Am. Chem Soc. 73, 3055 (1951).

8) C.E. Bawn, D. Margerison, Trans. Faraday Soc. 51, 925 (1955) ; A.I. Yurzhenko, O.P. Brazhnikova, N.M. Likholet Ukrain. Khim. Zhur. 21, 586 (1955) ; C.A. 50, 9182 (1956).

9) H. Galiba, $Z$. anorg. allgem. Chem. 287, 152 (1956); M.S. Tsao, J. Phys. Chem. 63, 346 (1959).

10) C.A. Bunton, D.R. Llewellyn, Research 5, 142 (1952); A.I Brodskii, Doklady Akad. Nauk. S.S.S.R. 115, 934 (1857).

11) M.S. Tsao, W.K. Wilmarth, Disc. Faraday Soc. 29, 137 (1960).

12) S. Fronaeus, Acta Chem. Scand. 9, 902 (1955) ; A. Kailan L. Olbrich, Monatsh 47, 449 (1927); C.A. 23, 3148 (1929).

13）藤田重文, 東畑平一郎, 「化学工学 III] p. 11, 57 (1963), 東京化学 同人

14）日本化学会糄「化学便豎」 p. 544 (1958), 丸善

15) J. Weiss, Proc. Roy. Soc. [A] 147, 3ลิ2 (1932); Trans Fa raday Soc. 31, 668 (1935).

16）田村和子，触媒 1，112 (1959)；W.C. Schumb, C.N. Satterfield, R.L. Wentworth. "Hydrogen Peroxide" p. 473 (1955). Reinhold, New York.

17) W.C. Schumb, Ind. Eng. Chem. 41, 992 (1949)

18) D.F. Othmer, Ind. Eng. Chem. 20, 743 (1928).

19) E.D. Wilson, H.C. Ries, "Principles of Chemical Engineering Thermodynamics” p. 279 (1956), McGraw-Hill, New York

20) K. Wohl, Trans. A. I. Ch. E. 42, 215 (1946), Chem. Eng. Progr. 49, 218 (1953)

21) E.W. Washburn, "International Critical Table ill. p. 213 (1928), McGraw-Hill, New York

22) 内田俊一，小川茂，化学機械 12，97 (1948)。

23) J.J. Van Laar, Z. Phys. Chem. 72, 723 (1910); 83, 599 (1913). 